\title{
Sexually transmitted diseases in nineteenth and twentieth century India
}

\author{
David Arnold
}

\begin{abstract}
Although the current AIDS epidemic in India might (if recent predictions of its likely impact prove correct) drastically transform the situation, sexually transmitted diseases (STDs) have rarely in the past received the degree of attention their widespread distribution deserved. The reasons for this neglect, briefly stated, are these-the official preoccupation with "major" epidemic diseases with high mortality levels, the limited constituency addressed by (or accessible to) state medicine and public health services, and the powerful cultural, social and economic forces which have facilitated the spread of STDs while inhibiting their effective observation and control.
\end{abstract}

\section{Historical epidemiology}

Some attempts have been made to identify syphilis and gonorrhoea in ancient Hindu (Äyurvedic) texts, but the evidence strongly suggests that syphilis at least was unknown in India before the early sixteenth century. Some of the first references to the disease and its treatment are to be found in the Bhavaprakasa, a mid-sixteenth-century text, reputedly the work of Bhavamisra, an Ayurvedic physician at Benares. At that date, and for a long time subsequently, syphilis was known in India as firanga or firangi roga, terms which identified it with the firangis ("Franks") or Europeans. Whatever the origins of syphilis elsewhere, it seems probable that the disease was introduced to India from Europe by the Portuguese in the early sixteenth century. ${ }^{1}$ By the early nineteenth century, when the British had gained ascendency over a large part of the subcontinent, syphilis was already widely disseminated, though the extent of its incidence can only be guessed at. In 1808 a British doctor in Mysore ranked syphilis next to smallpox as one of "the most destructive and most perilous disease[s] in India", and claimed that few middle-aged males were entirely free of it. ${ }^{2}$

Historically and statistically, STDs in India have posed two particular problems. The stigma attached to such diseases has, as elsewhere, encouraged their concealment while their apparently non-fatal nature has resulted in their virtual absence from the mortality data. Information on morbidity has always been seriously defective in India. Thus it was only in the army, where both the opportunities for observation and the political imperatives for detection and treatment existed side by side, and not among the civilian population, that statistical data about STDs were first systematically recorded. In the first half of the nineteenth century STDs were known to be widely present among European soldiers. In 1805, for instance, an assistant surgeon of the East India Company in Trichinopoly in south India referred to the "great havoc" wrought by venereal disease among European troops stationed in the town. ${ }^{3}$ But until the 1850 s the incidence of debilitating but rarely fatal STDs was overshadowed by heavy mortality from cholera, malaria, dysentery, and other causes. However, coming in the wake of the Crimean War and the reforms in army nursing and medical provision instituted by Florence Nightingale, the Indian Mutiny and Rebellion of 1857-8 highlighted the atrocious state of health among European soldiers in India. The uprising also raised the political commitment to soldiers' health by increasing British reliance upon white rather than Indian troops for the maintenance of colonial power in South Asia. The Royal Commission on the Sanitary State of the Army in India, which reported in 1863, stressed the imperative need for drastic improvements in the health of European soldiers in India: venereal disease was an important element in this. ${ }^{4}$ Moreover, as the scale of mortality among British troops declined from 32 per 1,000 in $1860-64$ to 15 in 1890-94 and barely 4 in $1910-14,{ }^{5}$ attention shifted to leading causes of morbidity, and in the army for much of the second half of the nineteenth century, STDs stood second only to "malarial fevers" as a cause of hospitalisation.

Though no clear distinction was yet made between syphilis and other venereal infections, the full extent of STDs in the army first became clear around the middle of the nineteenth century. In Bengal, the province in which the majority of European soldiers were stationed, 177 men out of every thousand were admitted to hospital in 1855 for the treatment of STDs. Following the influx of large numbers of British troops during the Mutiny campaigns, the figure rose steeply to 359 admissions per 1,000 men in 1859 , only to fall back to 167 in 1867 . The introduction of the short-service system into the British Army in 1870 resulted in an increased proportion of young, unmarried soldiers being sent to India. By $188041 \%$ of British soldiers in India were under 25 years old, with a further $34 \%$ between the ages of 25 and 29 . Though officially $12 \%$ of British soldiers were permitted to have wives with them "on the strength," the actual proportion was far small- 
er: only $3.7 \%$ in 1890 , for example, with as few as $2 \cdot 8 \%$ in the infantry. ${ }^{6}$ The recourse to infected Indian prostitutes by young, unmarried soldiers was seen to be the primary explanation for the high incidence of STDs in the army. The number of hospital admissions (identified in almost equal proportion with primary syphilis and with gonorrhoea) rose to 205 per 1,000 in 1875 and peaked at 522 per 1,000 in $1895 .^{7}$ This was equivalent to more than half the army being hospitalised each year and the loss of more than a million military man-days. Although the number of deaths directly attributed to STDs was very small (less than $1 \%$ of the total in 1890), they were a significant cause of invaliding from the army (13.2\%). Moreover, a figure of 522 per 1,000 compared very unfavourably with the reported incidence of STDs among soldiers in Europe (104 in Italy, 44 in France, 27 in Germany) and among British soldiers stationed at home (212) or in other parts of the Empire. ${ }^{8}$ After 1895, however, the rate of admissions declined dramatically - to 276 per 1,000 in 1901, 117 in 1906 and 68 in 1909. By 1913 it was down to 53, virtually a tenth of the 1895 peak. $^{9}$

Among Indian soldiers the reported incidence of STDs was far lower than among Europeans. In 1877 the rate of admissions per 1,000 was 27 ; in 1890 it was 41 and in 1895,31 . However, these figures should be treated with caution: Indian soldiers before the First World War were subjected to far less medical scrutiny than British troops, and venereal complaints among them were probably significantly under-reported. ${ }^{10}$

Between the Mutiny and the First World War, STDs were viewed by state medicine almost exclusively in the context of army health and efficiency. In a manner that reflected colonial priorities at the time and the limited nature of the state's medical constituency, there was little apparent concern about the incidence of STDs among civilians-apart from the prostitutes associated with the army. Increased awareness of STDs came partly as a result of debates over the regulation of prostitution in Indian cities and cantonments and the slow growth of public health facilities. It also followed from the work of the Royal Commission on Venereal Diseases in Britian (1912-16). Its members included Mary Scharlieb who had previously practised medicine in India and who remained influential in women's medical circles there. The development of a women's medical movement in India from the 1880 s onwards was itself important in revealing the extent of STDs and related conditions among Indian women and children. A report on the Jafar Suleman Dispensary for women and children in Bombay by the pioneer woman doctor Edith Pechey recorded that among the 2,817 patients examined in the second half of 1884,74 women and 23 children were suffering from syphilis; 55 had gonorrhoea. " $\mathrm{M}$. I. Balfour, a leading member of the Women's Medical Service, remarked in 1924 on the basis of thirty year's work in India, that STDs
Table STD deaths and cases treated in Bombay, $1915-19^{13}$

\begin{tabular}{llll}
\hline & $\begin{array}{l}\text { Average } \\
1915-17\end{array}$ & 1918 & 1919 \\
\hline Deaths from gonorrhoea & 8 & 3 & 7 \\
Deaths from syphilis & 36 & 43 & 50 \\
Total deaths & 44 & 46 & 57 \\
Cases of gonorrhoea treated & 18,749 & 17,154 & 21,423 \\
Cases of syphilis treated & 49,061 & 39,154 & 45,610 \\
Total treated & 67,810 & 51,308 & 67,033 \\
\hline
\end{tabular}

were responsible for "much of the gynaecological disease which fills our women's hospitals, and also no doubt for much of the high rate of infant mortality and the many miscarriages and still-births." 12

But, despite an increasing clinical awareness of syphilis and gonorrhoea, statistical information remained scarce. Some confirmation of the extent of STDs was given in data prepared for the Bombay Prostitution Committee of 1921-2 (Table): Since Bombay in 1919 had a population in excess of one million, this suggests an incidence of at least 67 cases per 1,000, though some individuals may have been treated more than once in any given year. A survey by Sir John Megaw, Director-General of the Indian Medical Service, in 1933 reported 37 cases of syphilis and gonorrhoea for every 1,000 patients attending hospitals and clinics: it was also estimated that there were as many as 5.5 million cases of syphilis and 7.5 million of gonorrhoea in India at the time. ${ }^{14}$ But surveys of selected urban or institutional populations did not necessarily provide a reliable guide to the health status of the bulk of the population-those who lived in the countryside.

In several fields of medicine and public health India's independence in 1947 marked (or coincided with) a significant shift in state attitudes and resource allocation. But this was rather less the case with STDs, which for ten years after independence saw no fresh initiatives or improved techniques of reporting and surveillance. In his annual report for 1953 the Director-General of India's health services remarked that in the absence of an India-wide survey, it was difficult even to estimate the extent of STDs in the country. Because of the "stigma attached to the diseases", hospital and dispensary records were the only sources of information. They suggested that incidence was particularly high in seaport and industrial towns, but also in certain hill districts. ${ }^{15}$ In subsequent reports the Director-General further noted that, despite some initiatives by individual states of the Indian union, little had been done at an all-India level to co-ordinate information and to compile a more comprehensive record. $\mathrm{He}$ had no doubt, however, that "Venereal diseases constitute a major health problem in the country". ${ }^{16}$ In the mid-1950s, about 800,000 cases of STDs (with almost equal numbers of syphilis and gonorrhoea) were treated in hospitals and dispensaries throughout India, but some states provided more reliable information than 
others. ${ }^{17}$ At the time independent India directed its attention mainly towards combating such major epidemic diseases as smallpox and malaria. STDs were regarded as less lifethreatening and so commanded a far lower medical and administrative priority. Perhaps there was an element of moral judgement involved too-that those who contracted STDs did so as a result of their own promiscuity. International health agencies were also more inclined to fund eradication programmes for diseases like smallpox which had important international implications, though WHO did help to provide money and penicillin for a mass campaign in the Kulu Valley in Punjab in 1959, where the incidence of STDs was reported to be as high as $30 \% .{ }^{18}$ Only in the 1960 s and 1970 s were more effective measures introduced to try to contain STDs in India (see below).

The advent of AIDS in the 1980s was not at first regarded as a serious threat. India treated with complacency, even contempt, the idea that a disease identified with homosexuality and hence with the decadence of Western lifestyles could find an ecological niche in India: it was a white man's disease and retribution for Western immorality. A medical administration already burdened with massive health problems-including resurgent malaria, cholera and tuberculosiswas unwilling to recognise the existence of any additional threat to Indian health. In 1988 AIDS began to spread rapidly in India, but official reluctance to admit the presence of AIDS has until very recently hampered attempts even to define the scale of the epidemic. Although only 1,254 AIDS cases for the whole of Asia had been formally reported to WHO by the end of $1991,10,000$ has been suggested as a more realistic figure. Recent estimates put India alongside Thailand among the continent's principal AIDS and HIV-infected countries, with roughly 5 million HIV cases each. ${ }^{19}$ Bombay seems most heavily affected. Reports indicate that a third of Bombay's 50 to 100,000 prostitutes are already infected with HIV, and WHO experts have told the Indian Council for Medical Research that some 60,000 AIDS patients will need treatment in the city by 1995 . Some experts suggest that the epidemic in India is set to exceed even the scale of AIDS/HIV in Central Africa, with perhaps 5 million AIDS sufferers by the year $2000 .^{20}$

Therapeutic and control measures Until the First World War the commonest treatment for STDs among both European and indigenous medical practitioners was mercury. Mercury and its compounds were widely used by British physicians in early nineteenth-century India to treat a wide variety of complaints, including cholera and malaria, often with extremely adverse physical effects. One East India Company surgeon aptly remarked in the 1830 s that

"During the period of mercurial mania, how common an event was destruction of the nasal and palatine bones; and the men who were then said to have suffered in the wars of Venus, probably suffered more from the wars of Mercury". ${ }^{21}$

The use of mercury by practitioners of India's indigenous medical systems to treat syphilis either followed the Europeans to India in the sixteenth century or arose from a similarly humoral understanding of physiology and therapeutics. In addition, some Indian physicians recommended the use of sarsparilla (a recent import from the Americas) or a preparation of neem (margosa) leaves, a drug widely employed and revered in Ayurvedic and folk medicine in India. ${ }^{22}$ Trials with salvarsan began in India soon after the discovery of the drug by Ehrlich in 1909, but, given its cost, its use (in the form of intravenous injections) was at first confined to British soldiers. It probably contributed to, but came too late alone to have caused, the striking decline in the incidence of venereal diseases among British soldiers in India between 1895 and $1914 .^{23}$ By the 1920 s the use of salvarsan and neo-salvarsan was increasing, but some doubts were expressed about their safety and their ability to effect a lasting cure for syphilis. ${ }^{24}$

The military authorities in nineteenth-century India did not rely solely upon mercury to try to deal with STDs in the army. From about the 1780 s onwards lock hospitals were used to confine and treat prostitutes associated with the army and found to be suffering from STDs. In the Madras Presidency, for instance, there were up to a dozen such hospitals between 1810 and 1812: they treated nearly 1,600 women a year and claimed to "cure" $85 \%$ of them. ${ }^{25}$ But the career of India's lock hospitals was always controversial: they were for ever being abolished and then restored when no other adequate or more acceptable means of medical policing could be found. ${ }^{26}$ The military authorities found it preferable to tolerate, and even in effect to regulate and license Indian prostitution in the cantonments as a way of exercising some form of medical and disciplinary control over their troops and as a cheaper and more convenient alternative to a substantial increase in the number of soldiers' wives allowed "on the strength". To deny soldiers any kind of outlet for their sexual energies was thought impractical and dangerous to their physical and mental health. Thus rather than attempt to suppress prostitution in and around the army barracks, lock hospitals were reintroduced in the 1860 s through a series of cantonment acts in an attempt to combat rising levels of venereal disease. These measures were consolidated in the Contagious Diseases Act of 1864 which followed the lines of similar legislation in Britain, but this proved highly contentious. The Act was attacked by critics in Britain as well as India for effectively licensing, and thus approving, prostitution and for causing needless harassment and indecent outrages to the modesty of innocent women. But, moral issues apart, many doctors in India doubted the efficacy of lock hospitals: the incidence of STDs among soldiers 
continued to rise despite the regular inspection and confinement of infected prostitutes and the "cures" supposedly effected may only have been due to the temporary disappearance or suppression of the symptoms of the diseases. ${ }^{27}$

The abolition of the contagious diseases legislation in Britain in 1886 created strong pressure for the authorities in India to follow suit. In June 1888 the House of Commons passed a motion condemning the compulsory medical examination of women there: the Government of India was reluctantly forced to comply with this resolution and repeal its own Contagious Diseases Act in 1888 However, it was not prepared to abandon all controls over army prostitution and through a series of cantonment acts from 1889 onwards it retained many of the measures formally renounced the previous year. Despite the limited success of lock hospitals earlier, it would appear that the strict controls introduced at this time (coupled with health propaganda, improved recreational facilities and perhaps changing moral values among the soldiers themselves) helped first to check and then reverse the progress of STDs in the army..$^{28}$

But clearly such coercive and institutionally specific measures had little relevance to civilian society at large and the medical and administrative controls exercised over army prostitution were not replicated elsewhere. Prostitution was not illegal and the police authorities preferred that it remained openly practised in specific areas of a city rather than being driven underground and disseminated more widely. At the end of the First World War few Indian hospitals and dispensaries had any facilities for the investigation and treatment of STDs and many wished to avoid the stigma of association with them. As late as 1933 it was remarked that in Calcutta, the largest and wealthiest of India's cities, there existed "practically no organised treatment" for STDs. ${ }^{29}$ Bombay was more enlightened and in 1918 a special clinic was opened there by the local branch of the Empire-wide League for Combating Venereal Diseases, intended to serve the city's red light district. Significantly, this was not a state initiative, though the Bombay government did contribute to the clinic's running costs. ${ }^{30}$

As already indicated, the growth of a woman's health movement was responsible for important new initiatives in the investigation and treatment of STDs. The Dufferin Fund had been set up in 1885 to provide "medical aid" for the women of India and in the course of its work it brought to light the extent of venereal infection among women. The Women's Medical Service, founded in 1914 as an offshoot of the fund and with increased state support, tried to take up this issue in a more systematic way. In 1918 Dagmar F. Curjel of the WMS conducted an investigation into STDs among Indian women and her report provided much anecdotal evidence for the prevalence of STDs and their effects. One outcome of this was the introduction of special courses for medical women to improve their knowledge of STDs and to familiarise them with current treatment techniques. ${ }^{31}$ But further progress had to wait until after independence.

After the introduction of salvarsan 40 years earlier, a further therapeutic breakthrough came only with penicillin, which, by 1954 , India was producing for its own use. But, since STDs were a low health priority in India immediately after independence, little advantage was taken of this: state governments were preoccupied with "health problems of [a] more pressing nature", and hence "facilities for case-finding, contacts tracing, follow up and welfare work suffered." It was somewhat naively hoped that an act for the "suppression of immoral traffic" (passed in 1956) would itself have a "beneficial effect on checking the spread of venereal disease through prostitution." 32 The Government of India's first five-year plan (1951-56) virtually ignored STDs, and only with the second, in 1957 , were they brought into the mainstream of government health planning and funding. A Central Venereal Disease Organisation was established at a cost of Rs. 5,867,000 with the promise of improved diagnostic and treatment facilities, new epidemiological control measures and a health education scheme. STD clinics, hitherto a rarity, were to be established at both state and district levels. In 1960 there were two state and 20 local clinics. By 1965 the number had risen to five and 66 respectively and they were treating some 236,000 patients annually. Further additions to the programme were made in the fifth and sixth five-year plans. ${ }^{33}$ These measures went some way towards tackling the problem of existing STDs on an all-India scale, but the spectre of AIDS in the 1990s raises new and searching questions about the capacity of a Third World society like India to cope technically and administratively with a calamity of potentially much greater magnitude. The AIDS Prevention Bill of 1989, withdrawn in 1992 offered a poor palliative, and India is faced, at a time of severe economic crisis, with a sharply increased demand for scarce medical funding, resources, and trained medical staff.

\section{Social, cultural and economic \\ dimensions}

As elsewhere in the world, AIDS in India has been a powerful reminder of the social and cultural context of disease in general and of sexually-related diseases in particular. Influential factors here range from the physical and cultural environment and behaviour patterns of a society (or of specific groups within it) to the ways in which subjective understandings or "constructions" of disease shape public attitudes and inform state policies. $^{34}$ The nature of prostitution in India and attitudes towards it (a subject too vast and complex to be discussed here) are clearly of considerable importance in attempting to understand this aspect of STDs in nineteenth and twentieth-century India. Marriages between older men and sexually immature 
girls were sometimes cited as a reason why many men sought the company of prostitutes, with the result that both they and their childbrides in turn became infected with venereal diseases. Prostitution itself has long had an ambivalent status in India. It was sanctioned by certain indigenous religious and social practices and, as in the case of the army, partly condoned by the colonial administration. At the same time prostitutes often served as the vehicle for the expression of deep-seated racial and cultural prejudices. In colonial medical and administrative culture Indian prostitutes were condemned not just for the "immoral" nature of their profession but also in the belief that they were the means by which venereal and other diseases (such as typhoid) were communicated to otherwise "innocent" European soldiers and civilians. Indian culture has long had a place for female temple servants (devadasis) and for courtesans who were also singers and dancers: the dividing line between their religious and cultural functions and frank prostitution has often been obscure. But cultural traditions and social attitudes apart, other factors were also conducive to large-scale prostitution in colonial times and to the linkage with STDs. Port cities like Bombay and Calcutta owed their origins to European trade, conquest and administration: like their equivalents elsewhere in maritime Asia - Jakarta, Bangkok, Hong Kong and Shanghai-they became important both as centres of international trade and as critical links in the dissemination of epidemic diseases. Just as Bombay was the principal point of entry for bubonic plague in 1896 and for influenza in 1918, so has it served a similar role-importer, incubator, propagator-for AIDs in the 1980s and 1990s. The growth of Bombay and Calcutta as international ports and major commercial and industrial centres was a factor in the growth of their large prostitute populations. In 1922 there were said to be 5,000 Indian and more than 150 foreign (European and Japanese) prostitutes in Bombay and over 830 brothels: the city's police commissioner estimated that there were actually twice this number of prostitutes. ${ }^{35}$ Commerce and industry drew large numbers of immigrant males to the cities, but women tended to remain behind in the villages resulting in a striking urban predominance of men and a heavily skewed male/female ratio. The large number of prostitutes and brothels in Bombay and Calcutta was one consequence of this demographic imbalance.

There is also an important socio-economic element here. Although STDs like syphilis and gonorrhoea may not normally be directly related to poverty and malnutrition, they are certainly not unrelated. The famines which were such a frequent and devastating occurrence in nineteenth-century India (and again in Bengal in 1943) broke up families and drove women from the countryside into urban prostitution. Not only did they themselves fall prey to STDs: it was also noted that the incidence of such diseases among sol- diers rose markedly in famine years because of the influx of unregulated women offering themselves for prostitution at military barracks and cantonments. ${ }^{36}$ The scale of prostitution in Bombay today remains a crude human index of the extent of the poverty in Indian society, as well as of the continuing humiliation and exploitation of women. But the spread of AIDS in the city also reveals another socio-economic strand. In order to live poor city-dwellers sell their blood to clinics and hospitals: controls have been inadequate to prevent AIDS-infected donors from continuing to supply blood, thus spreading the virus beyond the prostitutes and their clients. Like almost every other major disease in India, AIDS is a disease of poverty: it is more than just a sexually transmitted disease. ${ }^{37}$

India also has a drug culture. Opium, hemp and other drugs have long been part of the Indian tradition-with an extraordinary range of medicinal, religious and criminal usages. Perhaps this wide acceptance and availability of drugs created a certain predisposition towards intravenous drug use in recent times. Certainly this is one of the routes by which AIDS has spread in the last few years in northeast India, close to drug producing areas of northern Burma. In January 1992 there were reported to be 30,000 drug addicts in the state of Manipur, 1,347 of them with AIDS. ${ }^{38}$

\section{Past perspectives and present problems}

This review of STDs in nineteenth- and twentieth-century India suggests that in the past-for a variety of social and administrative reasons-there has been a great reluctance or inability adequately to address the problems posed by such diseases. To the considerable obstacles of cultural and social taboos have been added the limited concerns of colonial and post-colonial governments and the sheer difficulty of monitoring-let alone treating-STDs. In India other, more evidently lethal, diseases have commanded a much higher public profile, and a correspondingly greater degree of state and professional concern. The difficulty of tackling AIDS today is partly due to the very different nature of the disease but it is also a legacy of that long-term problem. Moreover, in India, now as in the past, the sheer scale of health problems and the paucity of resources present major obstacles: poverty contributes both to the spread of a disease like AIDS and makes its containment or eradication even harder than in the affluent West.

1 Jolly J., Indian Medicine Delhi, Munshiram Manoharlal, 1977 (1st published 1901), pp. 3, 128-9

2 Ingledew to Physician-General, Madras, 23 Sept. 1808 Board's Collections F/4/345, India Office Library (IOL), London.

$3 \mathrm{~J}$. W. Price to Superintending Surgeon, Southern Division, 10 Feb. 1805, Board's Collections, F/4/200, IOL.

4 Royal Commission on the Sanitary State of the Army in India, London, HMSO, 1863 (Cmd 3184).

5 Balfour A. and Scott H. H., Health Problems of the Empire: Past, Present and Future, London, Collins, 1924, p. 128.

6 Annual Report of the Sanitary Commissioner with the 
Govermment of India 1890, p. 57

7 Annual Report of the Sanitary Commissioner with the Government of India 1895, p. 47.

8 Ibid., p. 46.

9 Annual Report of the Sanitary Commissioner with the Government of India 1914, p. 23

10 Sanitary Commissioner 1895, p. 65

11 First annual report of the Medical Women for India Fund, 1884 in Home, Medical, 32, Sept. 1886, National Fund, 1884 in Home, Medical,

12 Balfour M. I., 'Venereal disease in India', fournal of the Association of Medical Women in India, 12;3:1924, 15.

13 Report of the Prostitution Committee, Bombay, Government Central Press, 1922, appendix D, p. 13.

14 Report of the Health Survey and Development Committee I, Delhi, Manager of Publications, 1946, p. 123.

15 Annual Report of the Directorate-General of Health Services, 1953, New Delhi, Ministry of Health, n.d., p. 17

16 Annual Report of the Directorate-General of Health Services, 1957, New Delhi, Ministry of Health, n.d., p. 38

17 Ibid., p. 39.

18 Chopra R. L., 'Kulu Valley-mass V.D. control campaign, 1959', Indian fournal of Public Health, 1961; 5:49-55.

19 Chin J 'Global estimates of HIV infections and AIDS cases: 1991'. AIDS 1991: A Year in Review, S57.

20 Jayaraman K. S., "AIDS in India: Disaster looms in Bombay', Nature, 346, 9 Aug. 1990, p. 499; Herald (Panjim), 7 Jan. 1992, p. 2

21 Clark J, 'Report on syphilis in H.M. 13th Light Dragoons', Madras Quarterly Medical fournal, 1839; 1:409.

22 Jolly, Indian Medicine, p. 2; Chatterii K. K. ed., Syphilis in General Practice, Calcutta, Butterworth, 1920, p. 328

23 Annual Report of the Sanitary Commissioner with the Government of India 1913, p. 22.

24 Chatterii, Syphilis in General Practice, Calcutta, Butterworth 1920 , pp. 14-15.

25 Board's Collections, F/4/486, IOL.
26 Ballhatchet K., Race, Sex and Class under the Raj: Imperial Attitudes and Policies and their Critics, 1793-1905, London, Weidenfeld and Nicolson, 1980.

27 Editorials in Indian Medical Gazette, Apr. 1883, pp. 102-4; Apr. 1887, pp. 112-13; Brown D. B., "The pros 102-4, Apr. 1887, pp. 112-13; Brown D. B., "The pros and cons of the Contagious Diseases Act as applied to

28 Ballhatchet, Race, Sex and Class under the Raj 1793-1903, London, Weidenfeld and Nicolson, chapters 2 and 3 .

29 Maclean J. 'Opening address at the Medical Women's Maclean J. 'Opening address at the Medical Women's
Postgraduate Courses, Calcutta, June 26th 1933', fournal of the Association of Medical Women in India, 1933, 21:6.

30 Bombay Government Order 7133, 23 Aug. 1919, Genera Dept., Maharashtra State Archives, Bombay.

31 Balfour M. I. and Young R., The Work of Medical Women 59-60, 174.

32 Directorate-General of Health Services 1953, p. 17; Annual Report of the Directorate-General of Health Services, 19541956, New Delhi, Ministry of Health, p. 20.

33 Annual Report of the Directorate-General of Health Services 1960 , New Delhi, Ministry of Health, 1965, pp. 50-2; Health Services in India, 1981-82, New Delhi, Central Health Services in India, 1981-82, New Del

Bureau of Health Intelligence, pp. 11-12.
34 Brandt A. M. No Magic Bullet: A Social History of Venereal Disease in the United States since 1800, New York, Oxford University Press, 1987; Fee E. and Fox D. M. (eds) AIDS: The Burden of History, Berkeley, University of California Press, 1988.

35 Report of the Prostitution Committee, Bombay. Government Central Press, 1922. Appendix B.

36 Clark, "Report on syphilis", pp. 385-6; Annual Report of Ine Government of India 1900 , p. 25.

37 Karkaria BJ. "AIDS: You could be the next victim", Illustrated Weekly of India, 7 Jan. 1990, pp. 42-9.

38 Herald (Panjim), 9 Jan. 1992, p. 7 